\title{
CENTRAL COMPOSITE DESIGN ON THE VOLUME OF LASER METAL DEPOSITED Ti6A14V AND Cu
}

\author{
CENTRALNO NAČRTOVANJE KOMPOZITA NA OSNOVI \\ KOLIČINE LASERSKO NANEŠENE KOVINE Ti6Al4V IN Cu
}

\author{
Mutiu F. Erinosho, Esther Titilayo Akinlabi \\ University of Johannesburg, Department of Mechanical Engineering Science, Auckland Park Kingsway Campus, 2006 Johannesburg, \\ South Africa \\ mferinosho@uj.ac.za,mutiuerinosho1@gmail.com
}

Prejem rokopisa - received: 2016-01-20; sprejem za objavo - accepted for publication: 2016-05-18

doi:10.17222/mit.2016.019

\begin{abstract}
The laser technology process is a pulsating practice in the field of engineering and in all paces of lifespan; since it can travel a longer distance and be focused on a very small bright spot that exceeds the illumination of the sun. This present study reports on the modeling and the prediction of the volume of laser-deposited composites using the central composite design (CCD). Four input factors were put into consideration, which is the laser power, the scanning speed, the powder flow rate and the gas flow rate. Titanium alloy (Ti6Al4V) and copper $(\mathrm{Cu})$ powders were coaxially deposited to form the bulk of a single clad. The factors considered determine the energy density and the melt pool delivered into the substrate and as such, influence the volume of the deposited composite (VDC) that was employed in the response surface methodology (RSM) design. This has been used to predict the actual process parameters for the optimum process setting.
\end{abstract}

Keywords: laser metal deposition, response surface methodology, central composite design, volume of deposited composite

Postopek laserske tehnologije se uporablja na področju tehnike in na vseh korakih življenjske dobe materialov; saj lahko premaguje velike razdalje in je v obliki zelo majhne svelte točke, ki presega sevanje sonca. Studija predstavlja modeliranje in napovedovanje količine lasersko nanešenega kompozita, z uporabo centralnega načrtovanja kompozita (angl. CCD). Obravnavani so bili štirje vplivni dejavniki: moč laserja, hitrost skeniranja, hitrost toka prahu in hitrost toka plina. Titanova zlitina (Ti6Al4V) in baker $(\mathrm{Cu})$ sta bila koaksialno nanešena in sta tvorila enoten nanos. Obravnavani dejavniki so določali gostoto energije in obseg taline nanešene na podlago in kot taki vplivali na volumen nanešenega kompozita (angl. VDC), ki je bil uporabljen pri načrtovanju metodologije odgovora površine (angl. RSM). To je bilo uporabljeno za napovedovanje dejanskih procesnih parametrov pri optimiranju nastavitev procesa.

Ključne besede: nanašanje kovine z laserjem, metodologija odgovora površine, centralno načrtovanje kompozita, volumen nanešenega kompozita

\section{INTRODUCTION}

The word laser is an acronym for "Light Amplification by Stimulated Emission of Radiation". In terms of wavelength, a laser device produces intense beams of low-divergence light for electromagnetic radiation ranging from $1 \mathrm{~nm}$ to $1000 \mu \mathrm{m}$. It is less than $500 \mathrm{~nm}$ for ultraviolet and less than $800 \mathrm{~nm}$ in visible spectrum, and $200 \mathrm{~nm}$ to $400 \mathrm{~nm}$ for ultraviolet light. In comparison with photon energy, the wavelength of laser light is of a pure monochromatic type. ${ }^{1}$ The laser metal-deposition process produces a metallurgical bonding, which is formed permanently between the clad and the substrate. In applications, a low dilution occurs in one step, with the minimal use of powder; and no form of additional processing is required when this is achieved. ${ }^{2}$ The extent of the energy density absorbed by the substrate determines the depth of the melt pool and the volume of the deposited alloy. ${ }^{3}$ The material flow rate also has a large effect on the chemical and the mechanical properties of the final deposited clad during laser metal-deposition process. ${ }^{4,5}$
Design of experiment (DOE) has been widely used to minimize the guessing of results and useful for a laboratory experiment to yield a desirable output. It is a problem dependent on a set of experiments; and has been widely used in industries for the development and the optimization of production processes. ${ }^{6}$ It is also regarded as a systematic and rigorous approach to engineering problem-solving that applies techniques and principles during the collection stage of data, so as to ensure and arrive at a generally valid, defensible, and a well-aided engineering conclusion, which are carried out under the constraint of a minimal expenditure of engineering runs, time, and money. ${ }^{7}$ The first stage in DOE is the planning of the experiment before embarking on the process of testing and data collection. The second stage is the screening test; and this is used to identify the important factors that affect the process parameters under investigation from all the numerous potential factors. ${ }^{8}$ Optimization is followed in order to envisage the response values for all the likely factors within the experimental boundary and to locate the optimal experimental point. The next stage is done to ascertain that the approach 
used is robust enough to accommodate small alterations in the factor levels. ${ }^{6}$ The last stage is the verification of the results and the best-settings validation; and this is achieved by conducting a few follow-up experimental runs to confirm that the process parameters are well conformed. ${ }^{8}$ However, the effect of a specific factor can be evaluated at different levels of the other factors; therefore, the results will be reliable over the whole experimental space. ${ }^{9}$ The results showed how interconnected factors respond over a wide range of values, without requiring all the possible values to be tested directly. The software fits the response data to mathematical equations; which serve as models to predict what would happen for any given combination of values. ${ }^{10} \mathrm{~A}$ fullfactorial design with CCD to investigate the effects of $\mathrm{pH}$ and the buffer concentration of catholyte on the performance of two-chamber microbial fuel cell. It was revealed that the maximum power density did not show good manipulation on the fuel cell at a high level of buffer concentration. ${ }^{11}$ The relationship between a high sharpness and the configurations of the vortex finder of a hydrocyclone was modeled using the regression method. ${ }^{12}$ The production of recycled titanium from acid with the high sharpness was achieved.

A series of predictions have been made in an experiment in order to generate the validity of the result and to optimize the process parameters. In the literature, there are paucities of work on the estimation of the volume of laser-deposited samples. This can be really helpful to determine the bulk measurement of a laser-cladded surface. However, the aim of this work is to apply a full-factorial design and response surface methodology to evaluate and predict the volume of the laser-deposited titanium and copper alloys using the central composite design. The amount of volume generated is proportional and dependent on the laser's energy density and the process parameters employed.

\section{EXPERIMENTAL PART}

The process model started with several input factors such as the laser power, scanning speed, powder flow rate and gas flow rate that are controlled and varied by the experimenter. One or more outputs are produced as the response, which is assumed to be continuous. ${ }^{7}$ The established experimental data are used to derive an empirical model containing the first- and second-order terms linking the outputs and inputs. ${ }^{13}$ Figure 1 shows the general model of a process or system.

The most common empirical models fit to the experimental data take either a linear form or a quadratic form. A linear model with two factors, $X_{1}$ and $X_{2}$, can be written as Equation (1):

$Y=\beta_{0}+\beta_{1} X_{1}+\beta_{2} X_{2}+\beta_{12} X_{1} X_{2}+$ Experimental error

From Equation (1), $Y$ represents the response for the given levels of the main effects; $X_{1}$ and $X_{2}$ and the $X_{1} X_{2}$ term are included to account for a possible interaction effect between $X_{1}$ and $X_{2}$. The constant $\beta_{0}$ represents the response of $Y$ when both the main effects are 0 .

A quadratic model, which is a second-order model, is typically used in response surface DOE with suspected curvature; and it does not include the three-way interaction term, but adds three more terms to the linear model, as illustrated in Equation (2): ${ }^{13}$

$$
\beta_{11} X_{1}^{2}+\beta_{22} X_{2}{ }_{2}+\beta_{33} X^{2}{ }_{3}
$$

The response surface methodology (RSM) is an efficient statistical tool that has been used successfully in testing the process parameters and their interactive effects. ${ }^{14,15}$ In the RSM, the first-order design and the second-order design were adopted; and these are suitable for fitting and checking a first- and second-degree of polynomial. However, in other to allow for the efficient estimation of quadratic terms in the second-order model, a two-level factorial array is adopted, ${ }^{16}$ as shown in Equation (3):

$$
y=\beta_{0}+\sum_{i=1}^{k} \beta_{i} x_{i}+\sum_{i=1}^{k} \beta_{i i} x_{i}^{2} \sum_{i=1}^{k-1}+\sum_{j=2}^{k} \beta_{i j} x_{i} x_{j}
$$

If all the variables are assumed to be measurable, the response surface can be expressed as shown in Equation (4):

$$
y=f\left(x_{1}, x_{2}, x_{3}, x_{4}, \ldots, x_{k}\right)
$$

where " $y$ " is the independent variable of the system, and $x_{i}$ is the dependent variables or factors. $x_{1}, x_{2}, x_{3}, x_{4}, \ldots, x_{k}$ are the input factors, which influence the response $y ; \beta_{0}, \beta_{\mathrm{ii}} \beta_{\mathrm{ij}}$ are the unknown parameters. ${ }^{17-19}$

\subsection{Design of experiment}

The RSM was implemented in order to analyze the experimental variables, and to provide an average response to the values of the quantitative variables analyzed. The factors from the volume of the deposited Ti6Al4V/Cu composite (VDC) were employed for the RSM design; and these have been used to predict the

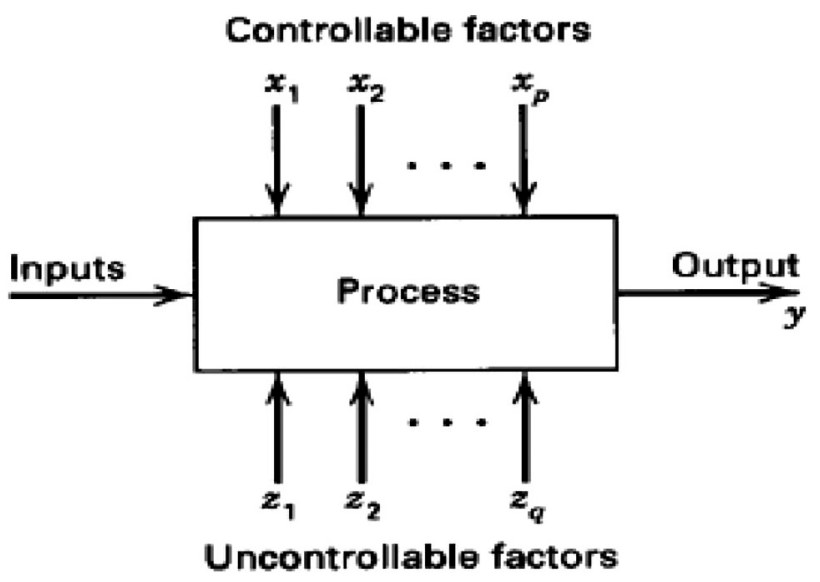

Figure 1: General model of a process or system ${ }^{9}$ Slika 1: Splošni model procesa ali sistema ${ }^{9}$ 


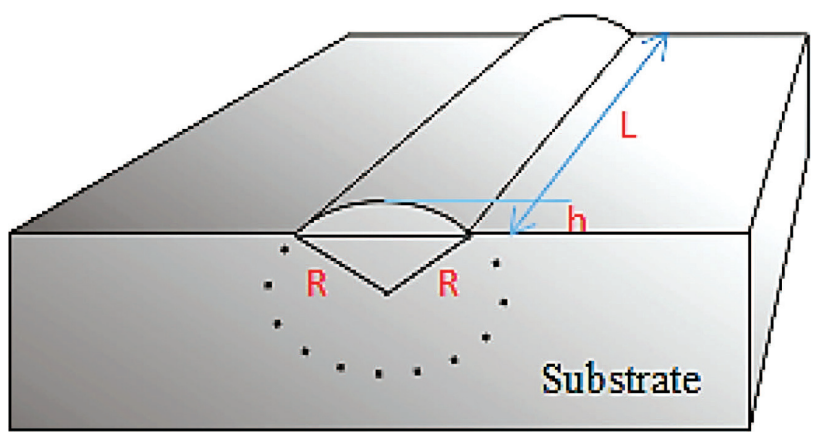

Figure 2: Schematic view of a laser-deposited sample ${ }^{20}$ Slika 2: Shematski prikaz lasersko deponiranega vzorca ${ }^{20}$

actual process parameters that produced the optimum process set-up. Figure 2 displays a schematic view of a deposited composite showing the track length, track width and the height of the deposit. The schematic is a sample image of the laser-deposited Ti6Al4V/Cu composite, as deposited on the substrate.

The volume of the laser-deposited composite is generated using Equation (5). The full geometry can be obtained elsewhere. ${ }^{20}$

$$
V(L, R, h)=L\left[R^{2} \cos ^{-1}\left(\frac{R-h}{R}\right)-(R-h)\left(\frac{W}{2}\right)\right]
$$

where $L$ designates the length of the deposit track; $W$ is the deposit width; $h$ is the height of the deposit; $R$ is the radius of the circle and $V$ represents the volume of the deposited composite.

The process parameters were controlled to give reasonable volumes of the deposited samples. The polynomial function is introduced in the RSM design to provide a depiction of how the response is affected by a number of variables over a unit of experimental interest.

The input parameters are the laser power, scanning speed, powder flow rate and the gas flow rate, respectively. In the settings, the low level and high level of the factors are the inputs, as shown in Table $\mathbf{1 .}$

Table 1: Input parametric factors for the RMS design

Tabela 1: Vhodni parametri dejavnikov za načrtovanje RMS

\begin{tabular}{|c|c|c|c|c|}
\hline Factor & Name & Level & Low Level & High Level \\
\hline A & Laser power & 1.60 & 0.80 & 1.60 \\
\hline B & $\begin{array}{c}\text { Scanning } \\
\text { speed }\end{array}$ & 0.60 & 0.30 & 0.90 \\
\hline C & $\begin{array}{c}\text { Powder } \\
\text { flow rate }\end{array}$ & 2.40 & 2.40 & 2.50 \\
\hline D & $\begin{array}{c}\text { Gas flow } \\
\text { rate }\end{array}$ & 2.95 & 2.90 & 3.00 \\
\hline \multicolumn{4}{|c|}{} \\
\hline
\end{tabular}

The VDC is studied by using the central composite design (CCD). This is appropriate to fit the quadratic

Table 2: Point-type design layout

Tabela 2: Postavitev točkaste vrste načrtovanja

\begin{tabular}{|c|c|c|c|c|c|c|c|c|}
\hline $\begin{array}{l}\text { Number of } \\
\text { run }\end{array}$ & $\begin{array}{l}\text { Standard } \\
\text { order }\end{array}$ & Block & Space type & $\begin{array}{c}\text { Laser power } \\
(\mathrm{kW})\end{array}$ & $\begin{array}{l}\text { Scanning } \\
\text { speed } \\
(\mathrm{m} / \mathrm{min})\end{array}$ & $\begin{array}{c}\text { Powder flow } \\
\text { rate }\left(\mathrm{min}^{-1}\right)\end{array}$ & $\begin{array}{l}\text { Gas flow } \\
\text { rate }(1 / \mathrm{min})\end{array}$ & $\begin{array}{l}\text { Volume of deposited } \\
\text { composite }\left(\mathrm{mm}^{3}\right)\end{array}$ \\
\hline 1 & 18 & Day 1 & Center & 1.40 & 0.40 & 2.45 & 2.95 & 100.54 \\
\hline 2 & 20 & Day 1 & Center & 1.40 & 0.40 & 2.45 & 2.95 & 100.54 \\
\hline 3 & 11 & Day 1 & Factorial & 1.20 & 0.50 & 2.40 & 3.00 & 78.68 \\
\hline 4 & 9 & Day 1 & Factorial & 1.20 & 0.30 & 2.40 & 3.00 & 91.9 \\
\hline 5 & 6 & Day 1 & Factorial & 1.60 & 0.30 & 2.50 & 2.90 & 147.88 \\
\hline 6 & 13 & Day 1 & Factorial & 1.20 & 0.30 & 2.50 & 3.00 & 91.90 \\
\hline 7 & 1 & Day 1 & Factorial & 1.20 & 0.30 & 2.40 & 2.90 & 91.90 \\
\hline 8 & 19 & Day 1 & Center & 1.40 & 0.40 & 2.45 & 2.95 & 100.54 \\
\hline 9 & 5 & Day 1 & Factorial & 1.20 & 0.30 & 2.50 & 2.90 & 120.29 \\
\hline 10 & 12 & Day 1 & Factorial & 1.60 & 0.50 & 2.40 & 3.00 & 104.48 \\
\hline 11 & 3 & Day 1 & Factorial & 1.20 & 0.50 & 2.40 & 2.90 & 78.68 \\
\hline 12 & 16 & Day 1 & Factorial & 1.60 & 0.50 & 2.50 & 3.00 & 104.48 \\
\hline 13 & 10 & Day 1 & Factorial & 1.60 & 0.30 & 2.40 & 3.00 & 111.65 \\
\hline 14 & 17 & Day 1 & Center & 1.40 & 0.40 & 2.45 & 2.95 & 100.54 \\
\hline 15 & 14 & Day 1 & Factorial & 1.60 & 0.30 & 2.50 & 3.00 & 147.88 \\
\hline 16 & 4 & Day 1 & Factorial & 1.60 & 0.50 & 2.40 & 2.90 & 104.48 \\
\hline 17 & 2 & Day 1 & Factorial & 1.60 & 0.30 & 2.40 & 2.90 & 111.65 \\
\hline 18 & 7 & Day 1 & Factorial & 1.20 & 0.50 & 2.50 & 2.90 & 78.68 \\
\hline 19 & 8 & Day 1 & Factorial & 1.60 & 0.50 & 2.50 & 2.90 & 104.48 \\
\hline 20 & 15 & Day 1 & Factorial & 1.20 & 0.50 & 2.50 & 3.00 & 78.68 \\
\hline 21 & 29 & Day 2 & Center & 1.40 & 0.40 & 2.45 & 2.95 & 100.54 \\
\hline 22 & 23 & Day 2 & Axial & 1.40 & 0.20 & 2.45 & 2.95 & 102.76 \\
\hline 23 & 22 & Day 2 & Axial & 1.80 & 0.40 & 2.45 & 2.95 & 120.76 \\
\hline 24 & 21 & Day 2 & Axial & 1.00 & 0.40 & 2.45 & 2.95 & 69.38 \\
\hline 25 & 30 & Day 2 & Center & 1.40 & 0.40 & 2.45 & 2.95 & 100.54 \\
\hline 26 & 28 & Day 2 & Axial & 1.40 & 0.40 & 2.45 & 3.05 & 100.54 \\
\hline 27 & 26 & Day 2 & Axial & 1.40 & 0.40 & 2.55 & 2.95 & 100.54 \\
\hline 28 & 27 & Day 2 & Axial & 1.40 & 0.40 & 2.45 & 2.85 & 100.54 \\
\hline 29 & 24 & Day 2 & Axial & 1.40 & 0.60 & 2.45 & 2.95 & 97.36 \\
\hline 30 & 25 & Day 2 & Axial & 1.40 & 0.40 & 2.35 & 2.95 & 98.58 \\
\hline
\end{tabular}


surface. The numerical factors were selected based on the number of factors. The numbers of factors involved are: the laser power, the scanning speed, the powder flow rate, and the gas flow rate. From the CCD formed, a full factorial type was proposed. The number of blockings selected was designated to be run for $2 \mathrm{~d}$, that is $\mathrm{d} 1$ and d 2 are proposed for the experiment. In total, 30 runs were involved for the experiment within the two days. This displays the graphical illustration of the blocks' interpretation in Table 2; and the orientation would be much more productive to the impact of the control factors in response to the surface graphics.

The quadratic model used was not aliased, which means there are no fewer independent points in the design model; therefore, the parameters used can be estimated independently. Aliases are calculated, based on the responses selected, and taking into consideration the degree of freedom for the evaluation.

Table 3 illustrates the power at a $5 \%$ alpha level to detect the signal or noise level in this model. The standard error estimates the standard deviation of the parameters; and it is used to calculate a confidence interval around the parameters.

The smaller the standard deviation, the better is the result. In this design, the Variance Inflation Factor (VIF) measures how much the variance of that parameters or model coefficient is inflated by the lack of orthogonality in the design. The VIF in this design follows between 1.0 and 1.05, which is almost ideal. The VIF above 10 indicates some cause for alarm; and this shows that the coefficients are poorly estimated - due to multi-collinearity. The ideal Ri-squared is 0.0 , which makes the model a good one. A high Ri-squared specifies that the terms are correlated with each other; and this could possibly lead to poor models. In this design model, the minimum, average and maximum variance mean are
$0.159,0.193$ and 0.588 , respectively. The average leverage for the 30 runs in the experiment is 0.5333 .

\section{RESULTS AND DISCUSSION}

\subsection{Analyses of the responses on the volume of the deposited composites within the CCD}

The results of the responses are numerically analyzed after the design evaluation. The resulting values of the VDC were input, based on the output from the number of runs within the design configurations. The design experts offer a full array of response transformation. The responses of the VDC range from the minimum value 69.38 $\mathrm{mm}^{3}$ and the maximum value $120.29 \mathrm{~mm}^{3}$. The ratio between the maximum and the minimum values is 1.73 . This obtained ratio is less than 3 ; and the power transformation would consequently have little effect.

In the analysis of the results, a model for the fit summary is suggested. The Sequential Model is formed with the combination of the source, sum of squares, degree of freedom (df), mean square, $F$ value and the p-value. A small $F$ value and a high p-value, which is greater than 0.1 , are good for the model. The lowest $\mathrm{F}$ value is 0.14 ; and the highest p-value is 0.9634 . These two values fall within the quadratic versus 2 factors interaction (2FI) of the Sequential Model.

However, the model may fit the design points at some point; but it may not be a very good predictor at the other points. Extra design points need to be added, to check the model fit; and these should be beyond those for determining the model coefficients. The variation between the model prediction and the extra points can be compared with the experimental or pure error, to test the lack of fit. The experimental error, or the pure error, is the normal variation within the response when there is a replicate of the experiment. Only one experiment was

Table 3: Power at $5 \%$ alpha level to detect the signal for various standard-deviation values

Tabela 3: Moč na $5 \%$ vsebnosti alfa za zaznavanje signala pri različnih standardnih vrednostih odstopanj

\begin{tabular}{|c|c|c|c|c|c|c|}
\hline Term & Standard error & VIF & Ri-squared & $\begin{array}{c}0.5 \text { Standard } \\
\text { deviation }\end{array}$ & $\begin{array}{l}1 \text { Standard } \\
\text { deviation }\end{array}$ & $\begin{array}{c}2 \text { Standard } \\
\text { deviation }\end{array}$ \\
\hline Day 1 & 0.19 & 1.00 & 0.0000 & & & \\
\hline \multicolumn{7}{|l|}{ Day 2} \\
\hline A & 0.20 & 1.00 & 0.0000 & $20.8 \%$ & $62.5 \%$ & $99.5 \%$ \\
\hline $\mathrm{B}$ & 0.20 & 1.00 & 0.0000 & $20.8 \%$ & $62.5 \%$ & $99.5 \%$ \\
\hline $\mathrm{C}$ & 0.20 & 1.00 & 0.0000 & $20.8 \%$ & $62.5 \%$ & $99.5 \%$ \\
\hline $\mathrm{D}$ & 0.20 & 1.00 & 0.0000 & $20.8 \%$ & $62.5 \%$ & $99.5 \%$ \\
\hline $\mathrm{AB}$ & 0.25 & 1.00 & 0.0000 & $15.4 \%$ & $46.1 \%$ & $96.0 \%$ \\
\hline $\mathrm{AC}$ & 0.25 & 1.00 & 0.0000 & $15.4 \%$ & $46.1 \%$ & $96.0 \%$ \\
\hline $\mathrm{AD}$ & 0.25 & 1.00 & 0.0000 & $15.4 \%$ & $46.1 \%$ & $96.0 \%$ \\
\hline $\mathrm{BC}$ & 0.25 & 1.00 & 0.0000 & $15.4 \%$ & $46.1 \%$ & $96.0 \%$ \\
\hline $\mathrm{BD}$ & 0.25 & 1.00 & 0.0000 & $15.4 \%$ & $46.1 \%$ & $96.0 \%$ \\
\hline $\mathrm{CD}$ & 0.25 & 1.00 & 0.0000 & $15.4 \%$ & $46.1 \%$ & $96.0 \%$ \\
\hline AČ2 & 0.19 & 1.05 & 0.0476 & $68.3 \%$ & $99.8 \%$ & $99.9 \%$ \\
\hline BČ2 & 0.19 & 1.05 & 0.0476 & $68.3 \%$ & $99.8 \%$ & $99.9 \%$ \\
\hline CČ2 & 0.19 & 1.05 & 0.0476 & $68.3 \%$ & $99.8 \%$ & $99.9 \%$ \\
\hline DČ2 & 0.19 & 1.05 & 0.0476 & $68.3 \%$ & $99.8 \%$ & $99.9 \%$ \\
\hline
\end{tabular}


run in the design space; and the pure error is negligible; since the value of the sum of the square and mean square in the lack of fit test table is zero. The lack of fit tests table compares the residual error with the pure error from replicated design points. Since the pure error is zero, the $\mathrm{F}$ value and the Prob $>\mathrm{F}$ were not revealed by the model (Table 4). The model has an insignificant lack of fit, which shows that it is a good predictor, and a better forecaster of the responses; and this follows the statistical and numerical output.

\subsection{Analysis of variance results}

The Analysis of Variance (ANOVA) is the statistical approach that partitions the total variation of a dataset into its component parts for the purpose of testing an assumption on the parameters of the certain selected model. The ANOVA is constructed totally on the basis that the factors are fixed, and the design is crossed. Table 4 depicts the ANOVA for the response surface quadratic model used. The quadratic model is a polynomial model containing the linear and two-factor terms. The sources in the response surface quadratic model include the block, the model, the factors, the residuals, and the lack of fit.

Table 4: Analysis of variance for the response surface quadratic model

Tabela 4: Analiza variance odziva površinsko kvadratnega modela

\begin{tabular}{|c|c|c|c|c|c|}
\hline Source & $\begin{array}{c}\text { Sum of } \\
\text { squares }\end{array}$ & Df & $\begin{array}{c}\text { Mean } \\
\text { square }\end{array}$ & F Value & $\begin{array}{c}\text { p-value } \\
\text { Prob }>\text { F }\end{array}$ \\
\hline Block & 74.57 & 1 & 74.57 & & \\
\hline Model & 7528.41 & 14 & 537.74 & 6.92 & 0.0004 \\
\hline $\begin{array}{c}\text { A-Laser } \\
\text { power }\end{array}$ & 4505.93 & 1 & 4505.93 & 58.01 & $<0.0001$ \\
\hline $\begin{array}{c}\text { B-Scanning } \\
\text { speed }\end{array}$ & 1554.46 & 1 & 1554.46 & 20.01 & 0.0005 \\
\hline $\begin{array}{c}\text { C-Powder } \\
\text { flow rate }\end{array}$ & 457.36 & 1 & 457.36 & 5.89 & 0.0293 \\
\hline $\begin{array}{c}\text { D-Gas flow } \\
\text { rate }\end{array}$ & 33.58 & 1 & 33.58 & 0.43 & 0.5215 \\
\hline AB & 24.68 & 1 & 24.68 & 0.32 & 0.5819 \\
\hline AC & 121.39 & 1 & 121.39 & 1.56 & 0.2317 \\
\hline AD & 50.37 & 1 & 50.37 & 0.65 & 0.4341 \\
\hline BC & 635.67 & 1 & 635.67 & 8.18 & 0.0126 \\
\hline BD & 50.37 & 1 & 50.37 & 0.65 & 0.4341 \\
\hline CD & 50.37 & 1 & 50.37 & 0.65 & 0.4341 \\
\hline$A^{\wedge} 2$ & 12.76 & 1 & 12.76 & 0.16 & 0.6914 \\
\hline$B^{\wedge} 2$ & 9.24 & 1 & 9.24 & 0.12 & 0.7352 \\
\hline$C^{\wedge} 2$ & 5.60 & 1 & 5.60 & 0.072 & 0.7923 \\
\hline$D^{\wedge} 2$ & 13.32 & 1 & 13.32 & 0.17 & 0.6851 \\
\hline Residual & 1087.38 & 14 & 77.67 & & \\
\hline Lack of fit & 1087.38 & 10 & 108.74 & & \\
\hline Pure error & 0.000 & 4 & 0.000 & & \\
\hline Cor total & 8690.36 & 29 & & & \\
\hline
\end{tabular}

From the source, the "F-value" of the Model is 6.92; and this infers that the model is significant. There is only a $0.04 \%$ chance that an "F-value" this large could occur due to noise. The values of "Prob > F" less than 0.0500 indicate that the model terms are significant. In other words and as indicated, A, B, C and BC are the significant model terms. Other values greater than 0.1000 , indicate that the model terms are not significant.

The values of the R-Squared and the adjusted R-Squared are good; since there values are close to 1 . The "Predicted R-Squared" of 0.1082 is not as close to the "Adjusted R-Squared" of 0.7476, as one might normally expect; and the difference is more than 0.2 ; and this may indicate a large block effect. The "Adequate Precision" measures the signal-to-noise ratio ${ }^{21}$ with a value of 11.481, which is desirable for the model; since its ratio is greater than 4 . This model can be used to steer and pilot the design space.

The final equation, in terms of the coded factors, is given in the following iteration, as shown in Equation (6):

Volume of Deposited Composites $=$

$99.98+13.70 * \mathrm{~A}-8.05 * \mathrm{~B}+4.37 * \mathrm{C}-1.18 * \mathrm{D}-1.24 * \mathrm{AB}+2.75$

$* \mathrm{AC}+1.77 * \mathrm{AD}-6.30 * \mathrm{BC}+1.77 * \mathrm{BD}-1.77 * \mathrm{CB}-0.68 * \mathrm{~A}^{\wedge} 2$

$+0.58 \mathrm{~B}^{\wedge} 2+0.45 * \mathrm{C}^{\wedge} 2+0.70 * \mathrm{D}^{\wedge} 2$

Equation (6) in the iteration of coded factors can be used to make predictions about the response for given levels of each factor. The coded equation is useful for identifying the relative impact of the factors by comparing the factor coefficients.

\subsection{Statistical analysis and the properties of the model}

The diagnosis and the statistical properties of the model are presented by normal probability plots. The studentized residuals are used to validate the ANOVA. The normal plot of residuals is a plot of normal percentage probability against the residuals. The data points are linear in the error term, which signifies no problems or difficulties in the data obtained from the probability distribution. Figure 3 shows the plot of percentage probability versus the externally studentized residual.

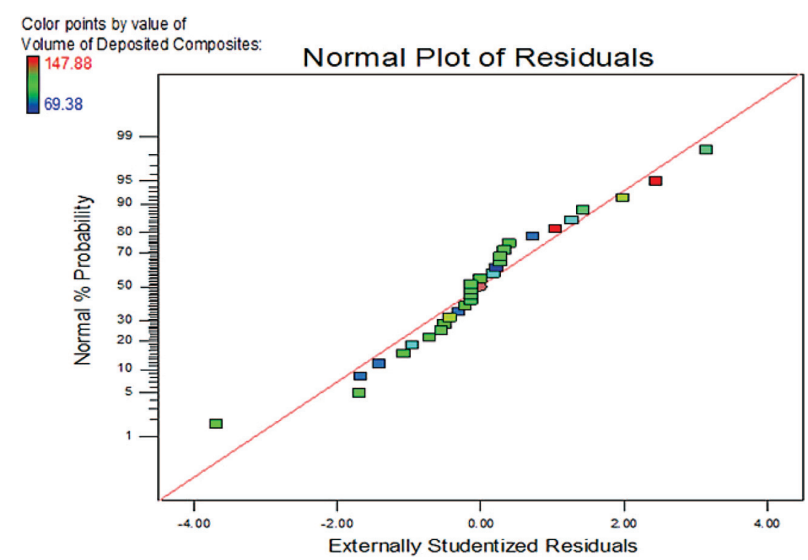

Figure 3: Plot of percentage probability versus the externally studentized residual

Slika 3: Diagram odstotka verjetnosti v primerjavi z zunanje proučevanim ostankom 


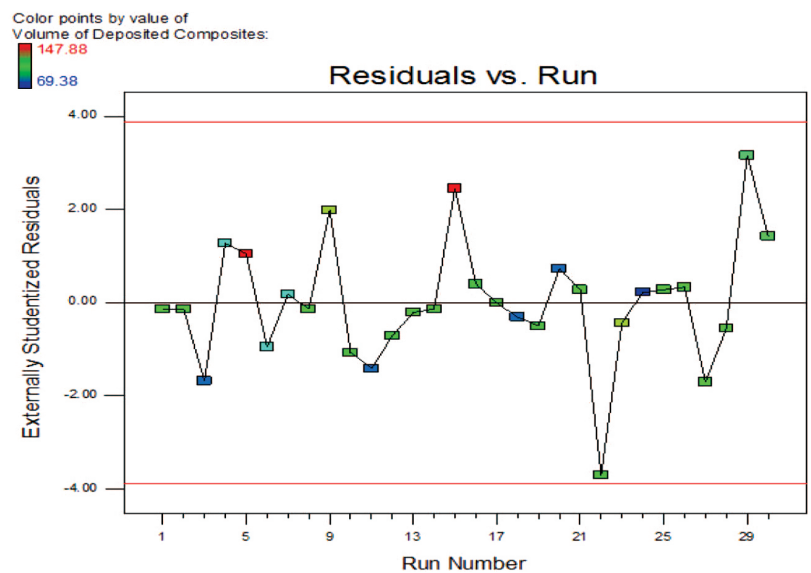

Figure 4: Plot of externally studentized residuals versus experimental run order

Slika 4: Diagram zunanje proučevanega ostanka v odvisnosti od eksperimentalnega poteka

The plot shows the way the actual value deviates from the predicted value. The Design-Expert puts control limits on the externally studentized residuals plot, in order to identify the abnormal runs easily. The externally studentized residual test or outlier t test is applicable when checking whether a run is consistent with the other runs; and is based on the assumption that the chosen model holds. The prediction of the responses at this point is made. In this model, there is no outlier and the responses fit the model, since the value is not greater than 3.5. This can be seen from the residual plots.

Figure 4 represents the plot of residuals versus the experimental run order.

This plot checks for lurking and unobserved variables that may have influenced the response during the experiment. The plot shows a random scatter with a line

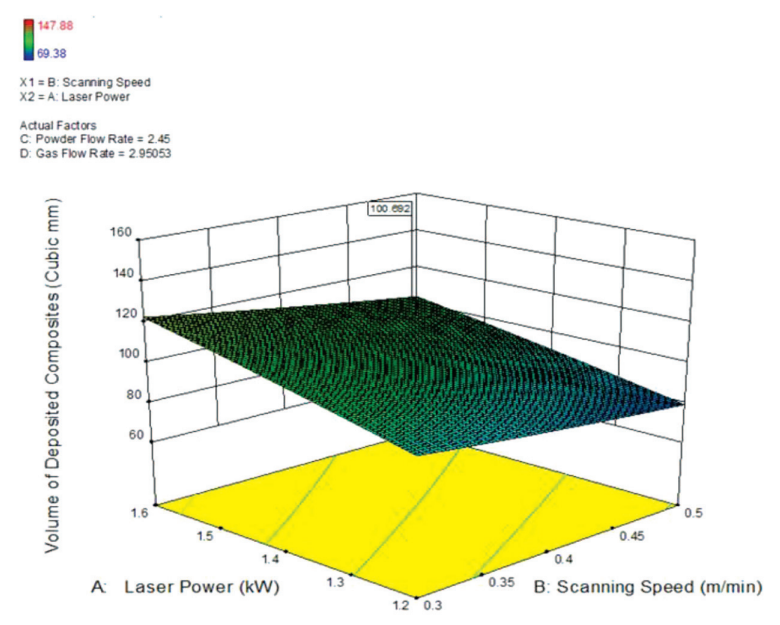

Figure 5: Surface plot of the volume of deposited composites at varying laser powers between $1.2 \mathrm{~kW}$ and $1.6 \mathrm{~kW}$, scanning speeds between $0.3 \mathrm{~m} / \mathrm{min}$ and $0.5 \mathrm{~m} / \mathrm{min}$

Slika 5: Površina volumna nanešenih kompozitov pri različnih močeh laserja med $1,2 \mathrm{~kW}$ in $1,6 \mathrm{~kW}$, hitrost skeniranja med $0,3 \mathrm{~m} / \mathrm{min}$ in 0,5 $\mathrm{m} / \mathrm{min}$ connecting each point. A consistent trend indicates a time-related variable lurking in the background of the plot. Randomization and blocking provide protection and indemnity for the trends, in order not to tarnish the analysis. The trend from the first run to the thirtieth runs falls between the upper and lower red lines. This proves the assumptions to be established, and most of the green points are found close to the zero point of the externally studentized residuals.

Figure 5 portrays the surface plot of the VDC at varying laser powers and scanning speeds, as well as a constant powder flow rate of $2.45 \mathrm{~min}^{-1}$, and a gas flow rate of $2.95053 \mathrm{~L} / \mathrm{min}$, respectively.

From the surface plot, it can be deduced that towards the direction of the laser power, an upward tilt or elevation of the surface plot was observed, as the laser power increases. Their representations indicate that an increase in the laser power leads to an increase in the volume of the composites, as directed by the upward tilt of the surface plot. The reverse is the case for the scanning speed on the same surface plot. Towards the path of the scanning speed, a downward tilt of the surface plot was observed, which indicates that the deposited volume decreases as the scanning speed increases. This phenomenon of the decrease in the volume with an increase in the scanning speed can be attributed
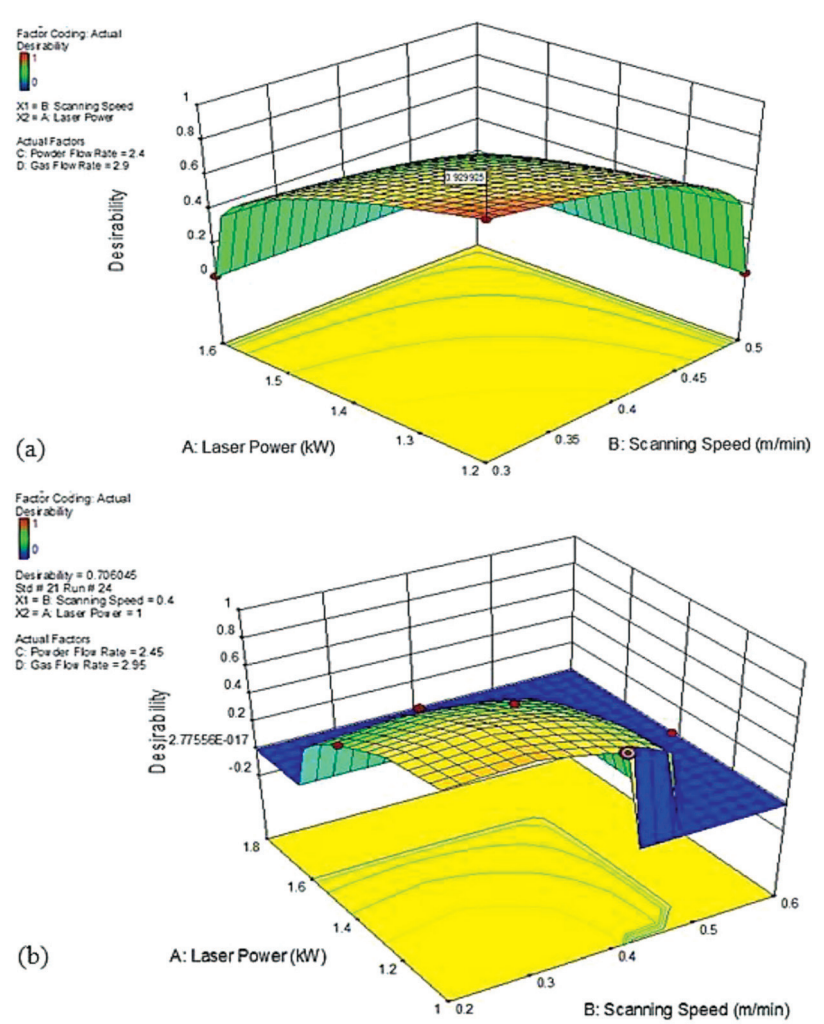

Figure 6: a) Surface plot of the desirability at varying lasers power and scanning speeds, b) surface plot of desirability with a standard order of 21 and run order of 24

Slika 6: a) Zaželjena površina pri različnih močeh laserja in hitrosti skeniranja, b) zaželjena površina z zahtevkom 21 in potekom 24 
to the interaction time it takes the powders to be formed on the surface of the substrate. In other words, the faster the speed of the scan, the quicker the time of deposit, and the smaller the deposited volume becomes, and vice versa. For this plot, the powder flow rate and the gas flow rate were kept constant.

The surface plot in Figures $6 \mathbf{a}$ and $\mathbf{6 b}$ shows a graphical representation and the response optimization of the normal desirability plot and the desirability with a standard order of 21 and a run order of 24 at varying laser powers between $1.2 \mathrm{~kW}$ and $1.6 \mathrm{~kW}$, and with a scanning speed between $0.3 \mathrm{~m} / \mathrm{min}$ and $0.5 \mathrm{~m} / \mathrm{min}$.

The contours of the desirability shortened inwardly as the laser power and the scanning speed decrease. This occurrence improves the desirability of achieving the optimal setting. The green and the faint red arcs drawn on the yellow square surface give an indication of the respective desirability. The desirability lies between the laser power of $1.2 \mathrm{~kW}$ and $1.4 \mathrm{~kW}$, and the scanning speed lies between $0.3 \mathrm{~m} / \mathrm{min}$ and $0.42 \mathrm{~m} / \mathrm{min}$. The $3 \mathrm{D}$ surface plotted ridge and fold are where the desirability can be maintained at a high level over a range of factor levels. The solution is relatively robust to a laser power between $1.6 \mathrm{~kW}$ and $1.8 \mathrm{~kW}$, and also robust to the scanning speed between $0.45 \mathrm{~m} / \mathrm{min}$ and $0.6 \mathrm{~m} / \mathrm{min}$. The robustness is indicated by the blue colour, and this shows that the approach used is robust enough to create a small alteration in the factor levels. ${ }^{6}$

\subsection{Validation of the experiment}

The experiment validation was established to verify the variations between the predicted value by the software and the actual value from the current experiment. This is actually done to validate and confirm the reality of the model. The actual results are almost twice the results predicted by the software. Figure 7 presents the plot of the actual value against the predicted value of the volume of the deposited composites.

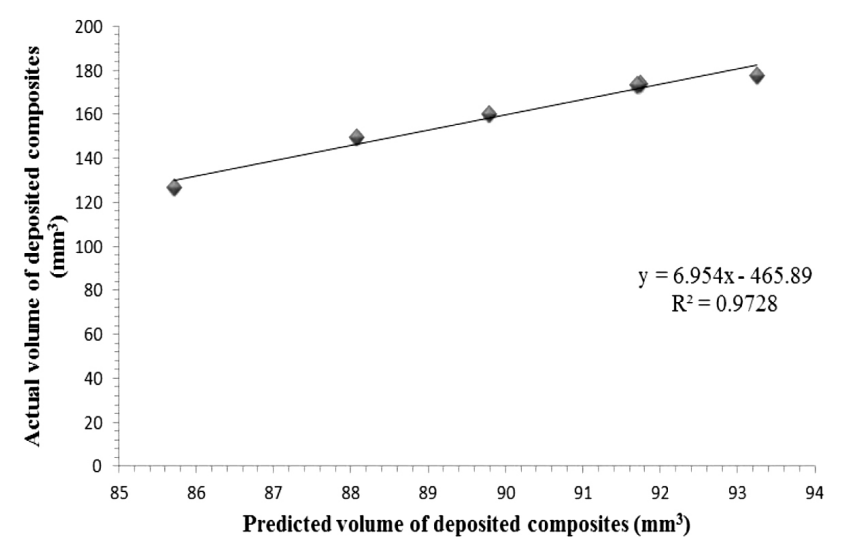

Figure 7: Plot of actual and predicted values for the volume of deposited composites

Slika 7: Prikaz dejanske in napovehanih vrednosti volumna nanešenega kompozita
The plot is a linear regression curve with the independent value of $y=6.954 x-465.89$. The values of y represent the actual values resulting from the experiment conducted on the selected parameters. The results obtained were approximately two times the predicted VDC. The laser system used for the trial runs and the preliminary studies was different from the laser system used to validate the results. The different laser-system configurations has a strong effect on the result. Also, the heights of the deposit undergoing validation have an influence on the actual results, which in turn affects the area of the segment and the volume of the composites.

\section{CONCLUSION}

This study discusses the application of RSM and CCD for the modeling and optimization of the effect of some operating variables on the volume of the deposited composite (VDC). It was observed that the cladded volume is directly proportional to the laser power and inversely proportional to the scanning speed. The model has an insignificant lack of fit, which shows that it is a good predictor, and a better forecaster of the responses, and this follows the statistical and numerical outputs. The mathematical model equations were derived for both the dependent variable (response) and the independent variables (input factors) using design expert software 9. The 3D response surface plots, which are simulations from the models, were presented to describe the effect of the process variables on the output volume. The F-value of the model was 6.92, which inferred that the model is significant. The value of the adjusted R-Square was 0.7476 and the adequate precision measures the signal-to-noise ratio with a value of 11.481 , which was desirable for the model.

\section{REFERENCES}

${ }^{1}$ Introduction to Laser Technology, http://www.mellesgriot.com, 12.07.2013

${ }^{2}$ Laser Solutions for Manufacturing, http://www.industrial-lasers.com/ articles/print/volume-250/issue-6/features/laser-metal deposition. html, Industrial Pennwell Copyright, 23.08.2013

${ }^{3}$ T. N Baker, Laser surface modification of Ti alloys, Surface Engineering of Light Alloys - Aluminium, Magnesium and Titanium Alloys, Wood-Head Publications, 2010, 398-443

${ }^{4}$ E. Brandl, A. Schoberth, C. Leyens, Materials Science and Engineering, A, 532 (2012) 295-307, doi:10.1016/j.msea.2011. 10.095

${ }^{5}$ M. Shukla, R. M. Mahamood, E. T. Akinlabi, S. Pityana, Effect of laser power and powder flow rate on properties of laser metal deposited Ti6A14V, World Academy of Science, Engineering and Technology, 2012, 71, 1268-1272

${ }^{6}$ L. Eriksson, E. Johansson, N. K. Wold, C. Wikstrom, S. Wold, Design of Experiments, Principles and Applications, (2010), 425

${ }^{7}$ Nist/Sematech, Engineering Statistic handbook, http://www.itl. nist.gov/div898/handbook/pmd/section3/pmd31.htm, 13.07.2014

${ }^{8}$ Reliability Engineering Resources, The eMagazine for the Engineering professionals, http://www.weibull.com/hotwire/issue84/hottopics84.htm, 15.04.2014 


\section{MATERIALI IN TEHNOLOGIJE/MATERIALS AND TECHNOLOGY (1967-2017) - 50 LET/50 YEARS}

\section{F. ERINOSHO, E. T. AKINLABI: CENTRAL COMPOSITE DESIGN ON THE VOLUME OF LASER METAL ...}

${ }^{9}$ D. C. Montgomery, Design and analysis of the experiments, $8^{\text {th }}$ ed New York, John Wiley \& sons, (2001), https://www.academia.edu/ 30544104/Douglas-C.-Montgomery-Design_and_Analysis_of_Exper iments-8th_edition

${ }^{10}$ M. Anderson, Design of Experiment, http://www.eng.auburn.edu/ $\sim$ drmills/mans486/DOE/Fall09/DOE_advantages_indust_examples.p df, 13.07.2014

${ }^{11}$ S. Madani, R. Gheshlaghi, M. A Mahdavi, M. Sobhani, A. Elkamel, Optimization of the performance of a double-chamber microbial fuel cell through factorial design of experiments and response surface methodology, Fuel, 150 (2015), 434-440, doi:10.1016/j.fuel.2015. 02.039

${ }^{12}$ B. Tang, Y. Xu, X. Song, Z. Sun, J. Yu, Numerical study on the relationship between high sharpness and configurations of the vortex finder of a hydrocyclone by central composite design, Chemical Engineering Journal, 278 (2015), 504-516, doi:10.1016/j.cej.2014. 11.022

${ }^{13} \mathrm{Nist} /$ Sematech, Engineering Statistic handbook, http://www.itl.nist. gov/div898/handbook/pri/section1/pri11.htm, 13.07.2014

${ }^{14}$ H. M. Hamzah, A. Osman, C. P. Tan, G. F. Mohamad, Carrageenan as an alternative coating for papaya (Carica papaya L. cv. Eksotika), Postharvest Biology and Technology, 75 (2013), 142-146, doi:10.1016/j.postharvbio.2012.08.012

${ }^{15}$ K. Murugesan, A. Dhamija, I. H. Nam, Y. M. Kim, Y. S. Chang, Decolourization of reactive black 5 by laccase, Optimization by response surface methodology, Dyes Pigments, 75 (2007) 1, 176-84, doi:10.1016/j.dyepig.2006.04.020
${ }^{16}$ G. E. P Box, K. B Wilson, On the Experimental Attainment of Optimum Conditions, Journal of the Royal Statistical Society, B, 13 (1951), 1-45

${ }^{17}$ N. Aslan, Y. Cebeci, Application of Box-Behnken design and response surface methodology for modeling of some Turkish coals, Fuel, 86 (2007), 90-97, doi:10.1016/j.fuel.2006.06.010

${ }^{18}$ N. Aslan, Application of response surface methodology and central composite rotatable design for modeling the influence of some operating variables of a Multi-Gravity Separator for coal cleaning, Fuel, 86 (2007) 5-6, 769-776, doi:10.1016/j.fuel.2006.10.020

${ }^{19}$ N. Aslan, Application of response surface methodology and central composite rotatable design for modeling and optimization of a multi-gravity separator for chromite concentration, Powder Technology, 185(1) (2008), 80-86, doi:10.1016/j.powtec.2007.10.002

${ }^{20}$ M. F. Erinosho, E. T. Akinlabi, S. Pityana, Effect of scanning speed and powder flow rate on the evolving properties of laser metal deposited Ti-6Al-4V/Cu composites, International Journal of Surface Science and Engineering, 3 (2016), 207-223

${ }^{21}$ G. E. P Box, N. R Darper, Empirical model-building and response surfaces, Wiley, New York, 1987 